\title{
The development of the Sabin-Pinkerton triad despite prenatal screening for congenital toxoplasmosis
}

\author{
Rozwój triady Sabina-Pinkertona mimo prowadzenia przesiewowych badań prenatalnych \\ w kierunku toksoplazmozy wrodzonej
}

\author{
'Department of Paediatric Infectious Diseases, Medical University of Lodz, Łódź, Poland \\ ${ }^{2}$ Department of Paediatric Ophthalmology, M. Konopnicka Paediatrics Center Central Clinical Hospital of the Medical University of Lodz, Kódź, Poland. Head: Associate Professor Anna Niwald \\ Correspondence: Associate Professor Ewa Majda-Stanisławska, Department of Paediatric Infectious Diseases, Medical University, Biegański Provincial Specialist Hospital, Kniaziewicza 1/5, 91-347 Łódź, \\ Poland, tel.: +48 $422516164,+484225160$ 18, e-mail: sekretariatcp@bieganski.com.pl
}

Abstract The paper presents a case of a boy who developed the symptoms of congenital toxoplasmosis: hydrocephalus, retinitis, choroiditis and intracranial calcifications (the Sabin-Pinkerton triad). Despite prenatal screening in the first trimester of pregnancy (in accordance with the guidelines of the Ministry of Health), which indicated the diagnosis of asymptomatic primary Toxoplasma gondii infection in the pregnant mother, no antiparasitic therapy was used. The presented serological and imaging findings, as well as specialist consultations confirm the intensified effects of congenital infection in the child. Although the child was put on anti-toxoplasma therapy immediately after birth, he developed severe psychophysical development disorders. The paper discusses recommendations for maternal diagnosis and antiparasitic treatment that could have prevented the full-blown congenital toxoplasmosis in the described patient.

Keywords: congenital toxoplasmosis, Sabin-Pinkerton triad, toxoplasmosis in pregnancy, diagnosis and treatment of congenital toxoplasmosis

W niniejszej pracy opisano przypadek chłopca, u którego doszło do rozwoju objawów toksoplazmozy wrodzonej: wodogłowia, zapalenia siatkówki i naczyniówki oka oraz zwapnień wewnątrzczaszkowych (triada Sabina-Pinkertona). Pomimo przeprowadzonych w I trymestrze ciąży (zgodnie z wytycznymi Ministerstwa Zdrowia) badań prenatalnych, których wyniki wskazywały na rozpoznanie pierwotnego bezobjawowego zarażenia Toxoplasma gondii matki w okresie ciąży, nie zastosowano terapii przeciwpasożytniczej. Przedstawione wyniki badań serologicznych, obrazowych i konsultacji specjalistycznych potwierdzają nasilenie skutków zakażenia wrodzonego u dziecka. Choć niezwłocznie po urodzeniu dziecka poddano je leczeniu przeciwtoksoplazmowemu, wystąpiły u niego poważne zaburzenia rozwoju psychofizycznego. W artykule omówiono rekomendacje dotyczące diagnostyki i leczenia przeciwpasożytniczego matki, które mogłoby zapobiec rozwojowi pełnoobjawowej toksoplazmozy wrodzonej u opisywanego pacjenta.

Słowa kluczowe: toksoplazmoza wrodzona, triada Sabina-Pinkertona, toksoplazmoza w okresie ciąży, diagnostyka i leczenie toksoplazmozy wrodzonej 


\section{INTRODUCTION}

$T$ bxoplasma gondii infection in pregnancy is associated with transplacental transmission of this protozoan, which may lead to serious fetal damage. Infections in the first trimester may result in intrauterine fetal death and pregnancy loss. In the case of infection in the second trimester, organ symptoms such as hydrocephalus, retinitis, choroiditis, and hepatitis prevail. Infection in the third trimester, even with no evident symptoms after birth, may cause retinitis and uveitis that recur later in life ${ }^{(1)}$.

\section{CASE REPORT}

\section{Pregnancy}

During pregnancy, the patient's mother was under the care of a gynaecologist who, following the perinatal care standards for women during physiological pregnancy, ordered a measurement of maternal levels of antibodies against toxoplasma. The test was positive (reactive) for $\operatorname{IgM}$ at 8 weeks gestation. Therefore, another assessment of antitoxoplasma antibodies was ordered at 11 weeks gestation, which was positive for the IgG class (high avidity). Another serology was performed at 16 weeks gestation. It was limited to IgM antibodies and again was positive (Tab. 1). No additional tests or anti-toxoplasmosis prevention were ordered. The mother denied any symptoms of infection during pregnancy. This was her second pregnancy. She was not tested for Toxoplasma gondii infection during her first pregnancy. A fetal ultrasound scan at 27 weeks gestation showed hydrocephalus with suspected bleeding into the central nervous system. After this examination, the mother was referred to a clinic at a higher reference centre, where a decision was made at 36 weeks gestation to terminate the pregnancy by caesarean section due to the deteriorating condition of the fetus.

\section{Neonatal period}

The child was born at 36 weeks from second pregnancy, second delivery, with a body weight of 3,180 g, an Apgar score of 9/9 and a Clinical Risk Index for Babies (CRIB) score of 1. The birth head circumference was $34 \mathrm{~cm}$. Transfontanellar ultrasound revealed the state after grade III intraventricular haemorrhage with dilation of the ventricular system and a significant dilation of the occipital horns (congenital hydrocephalus). Computed tomography (CT) of the head confirmed the presence of calcifications in the walls of the ventricular system and sectionally covering the surface of the cerebral hemispheres, including the subcortical ganglia (Figs. 1-4).

At 10 days of life, the level of anti-toxoplasma antibodies was measured, with positive results for all subclasses (Tab. 1). At the same time, neonatologists commissioned an analysis to compare the patterns of specific IgG and IgM bands from the maternal and neonatal blood using the Western blot method, and no differences were found between the bands. Although no specific DNA for Toxoplasma gondii was detected in the newborn's cerebrospinal fluid collected at 5 days of life and assessed with real-time polymerase chain reaction (RT-PCR), congenital toxoplasmosis was diagnosed based on the child's symptoms.

The boy's head circumference gradually increased, which required a neurosurgery and placement of Rickham reservoir at 24 days of life. Despite these measurements, hydrocephalus continued to increase by 8 weeks of age; the head circumference reached $41.5 \mathrm{~cm}$, which led to the decision to implant a ventriculoperitoneal shunt at 12 weeks of age.

\section{Four months of age}

At 4 months, the child's psychomotor development was described as delayed. The boy did not look around or grasp objects. When lying on his stomach, he did not raise his head or body. The consulting neurologist recommended electroencephalography (EEG), which showed interhemispheric asymmetry and significant paroxysmal changes in the left hemisphere. The boy was also under ophthalmological care due to temporal pigmented post-inflammatory foci found during an examination of the fundus of both eyes. The child failed to follow the light with his eyes, and rotary nystagmus appeared at extreme eyeball positions.

\section{Infancy}

In the months that followed, the delay in the child's psychomotor development became increasingly evident. The boy could not roll over unassisted, he did not raise his head or attempt to sit up. Decreased muscle tone and no eye contact were noticeable during physical examination. Intensive rehabilitation allowed to achieve a stable head hold at 11

\begin{tabular}{|c|c|c|c|c|c|c|c|c|}
\hline \multirow[b]{2}{*}{ Time } & \multicolumn{3}{|c|}{ Prenatal results } & \multicolumn{5}{|c|}{ Postnatal results } \\
\hline & 8 weeks & 11 weeks & 16 weeks & 10 days & \multirow{4}{*}{$\begin{array}{l}\rightarrow \text { Antiprotozoal } \\
\text { treatment onset }\end{array}$} & 4 months & 5 months & 9 months \\
\hline $\lg M$ & Positive* & - & Positive* & Positive* & & Negative & Negative & Negative \\
\hline $\lg G$ & - & $\begin{array}{l}\text { Positive* - } \\
\text { high avidity }\end{array}$ & - & $\begin{array}{c}\text { Positive } \\
(2,008 \mathrm{IU} / \mathrm{mL})\end{array}$ & & $\begin{array}{c}\text { Positive } \\
\text { (61.81 IU/mL) }\end{array}$ & $\begin{array}{c}\text { Positive } \\
\text { (36.6 IU/mL) }\end{array}$ & $\begin{array}{c}\text { Positive } \\
(25.4 \mathrm{IU} / \mathrm{mL})\end{array}$ \\
\hline $\lg A$ & - & - & - & Positive* & & Negative & Negative & Negative \\
\hline
\end{tabular}

Tab. 1. Tests for the levels of antibodies against toxoplasma performed for maternal peripheral blood during pregnancy and subsequent tests in the child after birth 


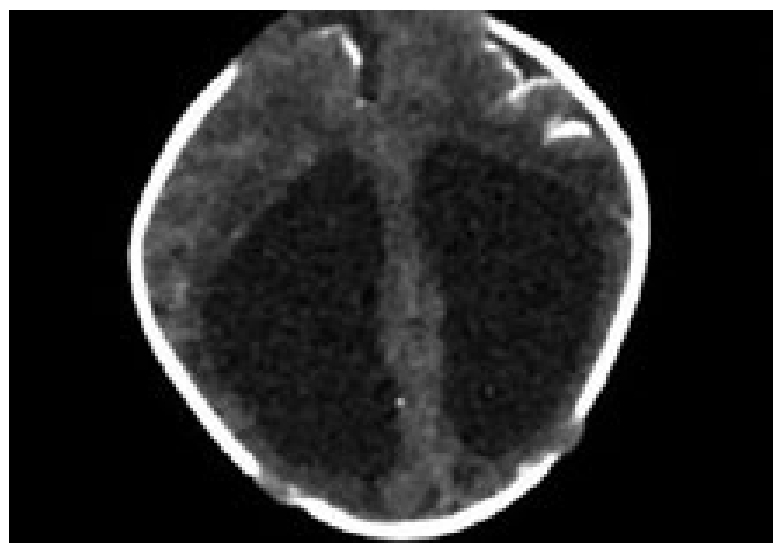

Fig. 1. CT scan of the patient's head - significant dilation of the lateral ventricles, calcifications in the cortical frontal lobes, more pronounced on the left side

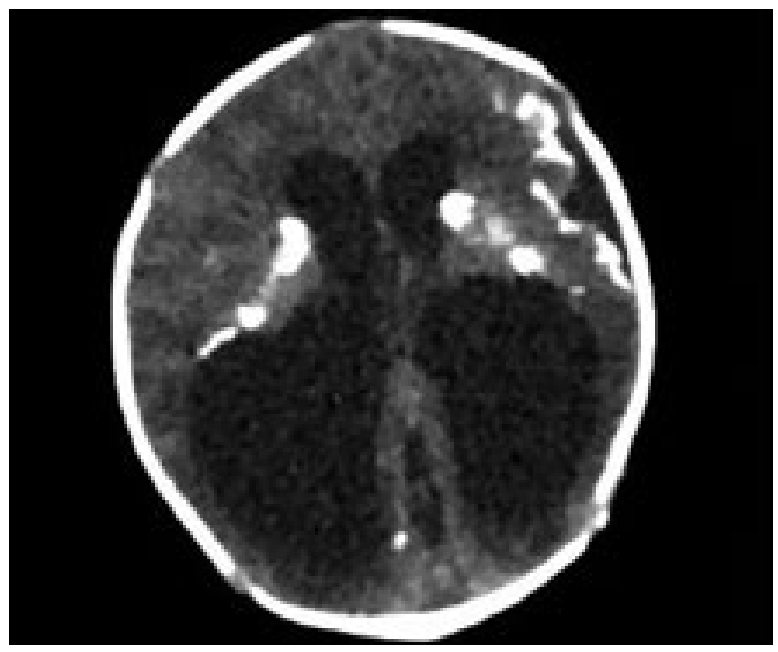

Fig. 2. CT scan of the patient's head - bilateral ventricular dilation with evident left-sided cortical calcifications and deep cerebral calcifications

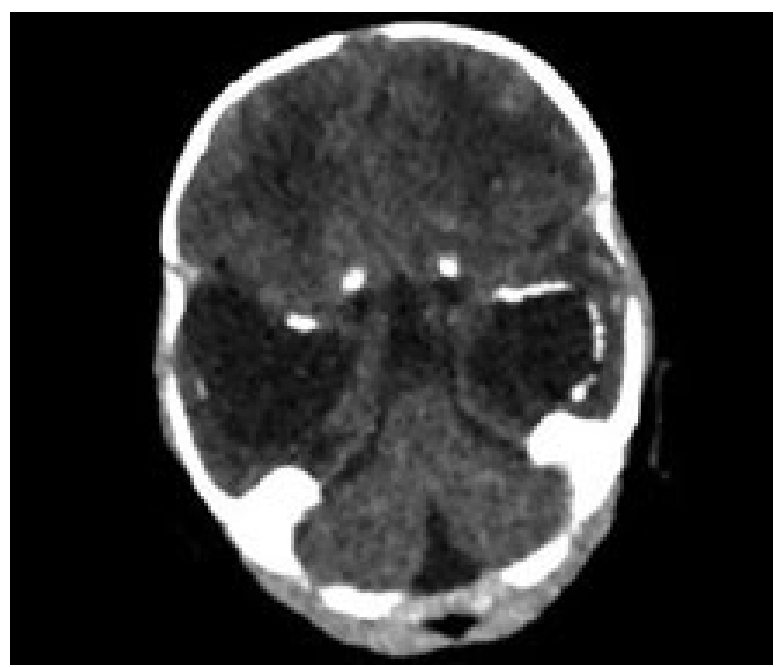

Fig. 3. CT scan of the patient's head - left-sided periventricular calcifications and bilaterally dilated temporal horns of the

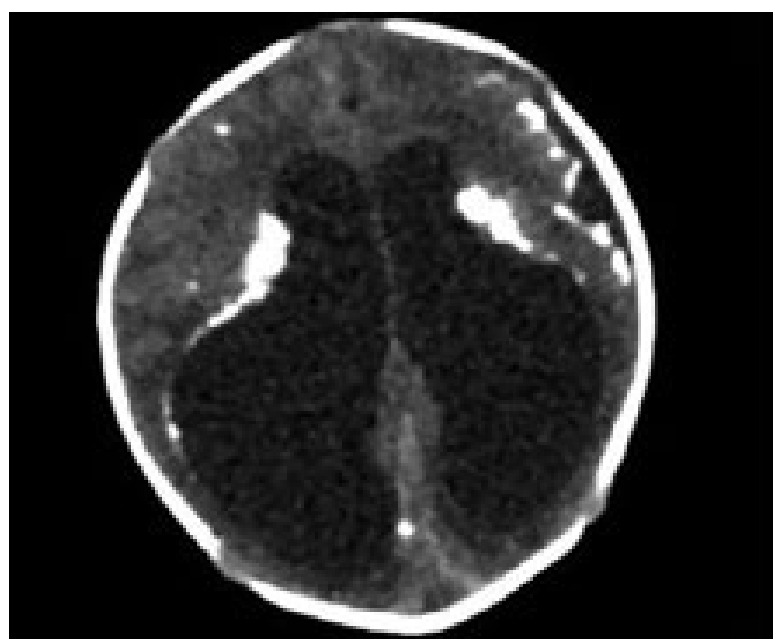

Fig. 4. CT scan of the patient's head - ventricular and deep cerebral calcifications, dilated ventricles

months, also when in a supported sitting position, and the baby began to rolling from the abdomen to the back.

The image of the changes in eye fundus at 12 months of age is presented in Fig. 5 .

A follow-up showed gradually decreasing IgG antibodies against Toxoplasma gondii. The levels of IgM and IgA antibodies remained negative throughout the treatment (Tab. 1). Admission to the department of neurology is planned after another neurological check-up to conduct extended diagnosis and make a decision about the possible introduction of anticonvulsants.

\section{Treatment}

At 12 days of life, the boy received inpatient antiprotozoal treatment with sulfadiazine, pyrimethamine and folinic acid, with doses adjusted for the child's body weight. The therapy was continued in the setting of department of infectious diseases and was planned to last 24 months.

\section{DISCUSSION}

Serological screening for toxoplasmosis in pregnant women was introduced in Poland in 2005. Its aim is to identify a group at high risk of congenital toxoplasmosis ${ }^{(2)}$.

The regulation of the Minister of Health of August 16, 2018, defines the organisational standards of perinatal care, including the screening for antibodies against toxoplasma:

1. by 10 weeks of pregnancy: "Testing for toxoplasmosis (IgG, IgM) unless the pregnant woman provides evidence confirming the presence of IgG antibodies from before pregnancy";

2. at 21-26 weeks of pregnancy: "In women with negative results in the first trimester - testing for toxoplasmosis $(\operatorname{IgM})^{\prime \prime(3)}$.

The Polish Society of Communicable Disease Epidemiologists and Physicians recommends screening for antibodies against 

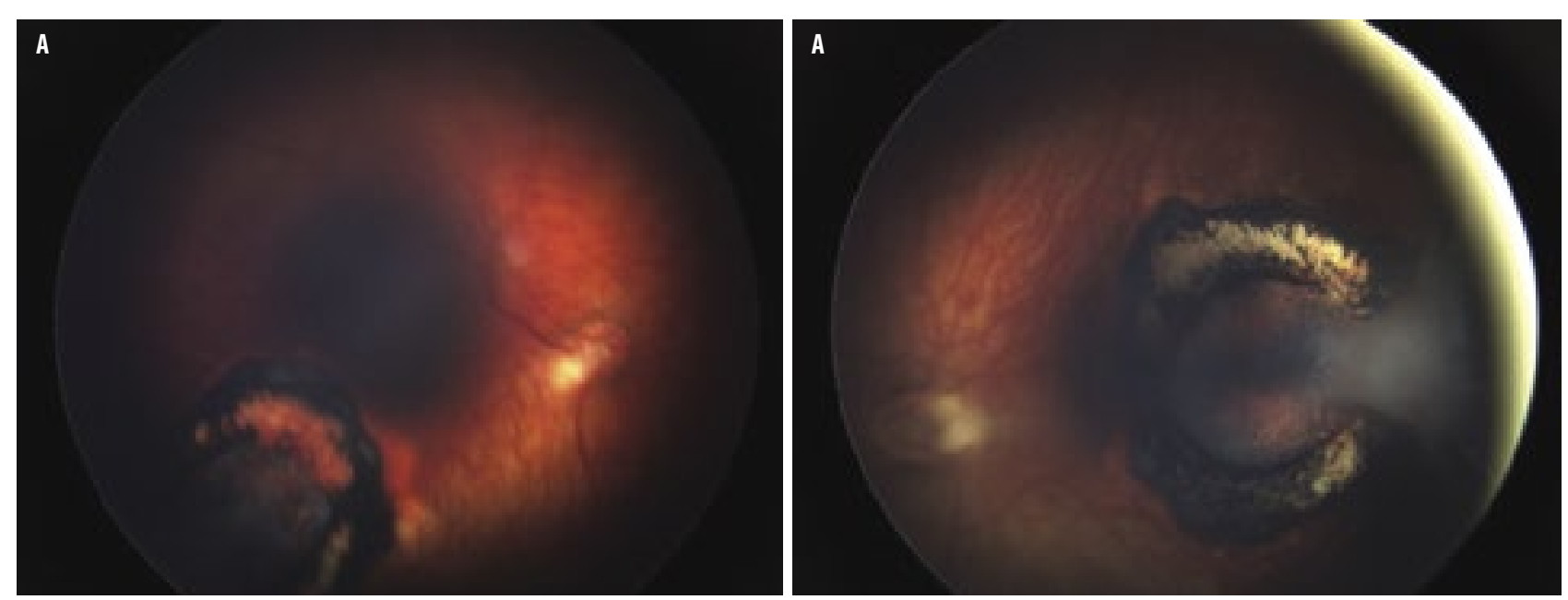

Fig. 5 A, B. Ocular lesions in congenital toxoplasmosis - fundus image recorded with RetCam 3 retinal camera (own resources). A. The right eye fundus. Extensive post-inflammatory scar in the posterior pole with features of retinal-choroidal atrophy and evident pigment aggregates partially covering the surface of the lesion. The centre of the scar is obscured by a translucent connective tissue membrane. Active cream-coloured inflammatory focus at the optic disc. Irregular course of retinal vessels. B. The left eye fundus. Post-inflammatory scar in the posterior pole with morphology similar to that in the right eye. The central part of the scar is connected to the vitreous body with a traction band of fibrous tissue, the peripheral part is clearly limited by a pigmented ring of retinal-choroidal atrophy. Active focal inflammation within the optic disc and in the maculopapular bundle-a cream-coloured, raised lesion with blurred outlines

Toxoplasma gondii in women who plan pregnancy to identify groups at high risk of toxoplasma infection ${ }^{(4)}$. If such tests have not been performed, the levels of antibodies should be measured simultaneously for both classes immediately after conception. In the case of a positive result in the IgM class, follow-up is recommended after 2-3 weeks, and then, in the case of another positive result for one of the antibody classes, chemoprophylaxis during pregnancy and continuation of serological tests every $2-3$ weeks are recommended. A positive result for both classes of antibodies against Toxoplasma gondii indicates a probable fetal infection, which can be confirmed by molecular testing of amniotic fluid collected during amniocentesis, preferably at 21 weeks gestation. If Toxoplasma gondii DNA is detected in the amniotic fluid, it is necessary to initiate antiprotozoal therapy ${ }^{(5)}$.

In the described case, positive $\operatorname{IgG}$ and $\operatorname{IgM}$ antibody tests at 8 weeks gestation indicated active toxoplasmosis and a serious risk of mother-to-fetus transmission at a very early stage of pregnancy ${ }^{(6)}$. In such a situation, it is recommended to measure maternal levels of anti-toxoplasma IgA antibodies and to initiate chemoprophylaxis with rovamycin at a dose of $3 \mathrm{~g} / \mathrm{day}$ until delivery. Assessment of the amniotic fluid collected around 21 weeks for the presence of toxoplasma DNA (PCR method) is another recommended diagnostic test. Detection of Toxoplasma gondii DNA in the amniotic fluid and/or ultrasonographic fetal abnormalities oblige to initiate antiprotozoal treatment with sulfadiazine and pyrimethamine instead of rovamycin in the pregnant woman ${ }^{(7)}$. Intracerebral calcifications, which are hallmark of this disease, confirmed the infection in the first CT scan of the patient's head. The examination of the eye fundus also showed the presence of post-inflammatory changes, confirming ocular toxoplasmosis ${ }^{(8)}$. The child presented with the Sabin-Pinkerton triad (retinochoroiditis, hydrocephalus, and intracranial calcifications), which is a manifestation of congenital toxoplasmosis ${ }^{(9)}$.

Antiprotozoal treatment was initiated at 12 days of the child's life, but its aim is to prevent further progression of the disease and reduce the risk of recurrence ${ }^{(10,11)}$. Currently, there is no treatment that could eliminate Toxoplasma gondii from the child's body, and the consequences of the changes caused by this protozoan will be evident throughout the boy's life.

\section{CONCLUSIONS}

In the described case, a positive IgG and IgM antibody test in the pregnant woman at 8 weeks gestation indicated active toxoplasmosis and a serious risk of mother-to-fetus transmission at a very early stage of pregnancy ${ }^{(12)}$. Despite the diagnostic findings, the child's mother was not referred for further diagnosis, and no prophylaxis or antiprotozoal treatment was recommended. After birth, the child presented with the Sabin-Pinkerton triad, which ultimately confirmed the diagnosis of congenital toxoplasmosis. This allows for the conclusion that the child's mother should have undergone extended diagnosis already during pregnancy and depending on the obtained results, prophylaxis or antiprotozoal therapy ${ }^{(13)}$. This is extremely important as antitoxoplasmic treatment initiated after birth cannot reverse the effects of Toxoplasma gondii infection, but can only inhibit further disease progression.

\section{Conflict of interest}

The authors do not declare any financial or personal links to other persons or organisations that could adversely affect the content of this publication or claim rights thereto. 


\section{References}

1. Niezgoda A, Dobrzańska A: Toksoplazmoza wrodzona - rozpoznawanie i leczenie. Przew Lek 2008; 11: 44-50.

2. Niezgoda A, Michalska E, Czech-Kowalska J et al.: Standard postępowania w toksoplazmozie wrodzonej. Stand Med Pediatr 2018; 15: 521-529.

3. Rozporządzenie Ministra Zdrowia z dnia 16 sierpnia $2018 \mathrm{r}$. w sprawie standardu organizacyjnego opieki okołoporodowej (Dz.U. z 2018 r., poz. 1756).

4. Milewska-Bobula B, Lipka B, Gołąb E et al.: Proponowane postępowanie w zarażeniu Toxoplasma gondii u ciężarnych i ich dzieci. Przegl Epidemiol 2015; 69: 403-410.

5. Soares JAS, Caldeira AP: Congenital toxoplasmosis: the challenge of early diagnosis of a complex and neglected disease. Rev Soc Bras Med Trop 2019; 52: e20180228.

6. SYROCOT (Systematic Review on Congenital Toxoplasmosis) study group; Thiébaut $\mathrm{R}$, Leproust $\mathrm{S}$, Chêne $\mathrm{G}$ et al.: Effectiveness of prenatal treatment for congenital toxoplasmosis: a metaanalysis of individual patients' data. Lancet 2007; 369: 115-122.
7. Mandelbrot L, Kieffer F, Sitta R et al.; TOXOGEST Study Group: Prenatal therapy with pyrimethamine + sulfadiazine vs spiramycin to reduce placental transmission of toxoplasmosis: a multicenter, randomized trial. Am J Obstet Gynecol 2018; 219: 386.e1-386.e9.

8. Kieffer F, Wallon M: Congenital toxoplasmosis. Handb Clin Neurol 2013; 112: 1099-1101.

9. Hampton MM: Congenital toxoplasmosis: a review. Neonatal Netw 2015; 34: 274-278.

10. Paul M, Szczapa J, Jaworska A et al.: Ocena skuteczności leczenia dzieci z toksoplazmozą wrodzoną rozpoznaną na podstawie pourodzeniowych badań przesiewowych. Przegl Ped 2003; 33: 46-53.

11. Paul M: Toksoplazmoza - groźna choroba pasożytnicza kobiet ciężarnych i pacjentów z osłabioną funkcją układu odpornościowego. Kosmos 2005; 54: 77-88.

12. Maldonado YA, Read JS; Committee on Infectious Diseases: Diagnosis, treatment, and prevention of congenital toxoplasmosis in the United States. Pediatrics 2017; 139: e20163860.

13. Serranti D, Buonsenso D, Valentini P: Congenital toxoplasmosis treatment. Eur Rev Med Pharmacol Sci 2011; 15: 193-198. 